\title{
A novel dinuclear schiff base copper complex as an efficient and cost effective catalyst for oxidation of alcohol: Synthesis, crystal structure and theoretical studies
}

\author{
ATENA NAEIMI $^{\mathrm{a}, *}$, SAMIRA SAEEDNIA ${ }^{\mathrm{b}}$, MEHDI YOOSEFIAN $^{\mathrm{c}}$, HADI AMIRI RUDBARI $^{\mathrm{d}}$ \\ and VIVIANA MOLLICA NARDO ${ }^{\mathrm{e}}$ \\ ${ }^{a}$ Faculty of science, Department of Chemistry, University of Jiroft, Jiroft, Iran \\ b Department of Chemistry, Vali-e-Asr University of Rafsanjan, Rafsanjan, Iran \\ ${ }^{c}$ Department of Chemistry, Graduate University of Advanced Technology, Kerman, Iran \\ ${ }^{\mathrm{d}}$ Faculty of Chemistry, University of Isfahan, Isfahan 81746-73441, Iran \\ 'Università degli Studi di Messina, dip. Scienze Chimiche. Viale Ferdinando S. d'Alcontres, \\ 98166 Messina, Italy \\ e-mail: naeimi.atena@imdea.org
}

MS received 22 November 2014; revised 17 April 2015; accepted 21 April 2015

\begin{abstract}
An environmentally friendly protocol is described for an economic, practical laboratory-scale oxidation of primary and secondary alcohols to aldehydes and ketones, using a bis-chloro-bridged binuclear $\mathrm{Cu}$ (II) complex $\left[(\mathrm{HL}) \mathrm{Cu}\left(\mu_{2}-\mathrm{Cl}\right)_{2} \mathrm{Cu}(\mathrm{HL})\right]^{*} 1.5 \mathrm{CH}_{3} \mathrm{OH}$ as catalyst. The catalyst was prepared in situ from commercially available reagents and is characterized by single crystal X-ray analysis, FT-IR, UV-visible spectra, mass spectrometry, and powder x-ray diffraction (PXRD). The geometry of the complex has been optimized using the B3LYP level of theory confirming the experimental data. Our results demonstrated well the efficiency, selectivity and stability of this new catalyst in the oxidation of alcohols in ethanol and tert-butyl hydroperoxide $(\mathrm{tBuOOH})$ as a green solvent and oxidant, respectively. Turnover number and reusability have proven the high efficiency and relative stability of the catalyst.
\end{abstract}

Keywords. Schiff base; Oxidation; DFT calculations; Peroxide; Green chemistry

\section{Introduction}

Development of efficient and selective catalyst for oxidation of alcohols to their corresponding carbonyl compounds is a vital prerequisite in the pharmaceutical, fragrance, flavoring and fine chemicals industries. ${ }^{1,2}$ These reactions are performed at present using harmful oxidants and they have many drawbacks and limitations Over the past decade, it was found that catalytic methods could potentially alleviate these problems. ${ }^{3}$ In this regard, Schiff base complexes are ideal catalysts having long-term shelf-stability and be readily prepared in situ from commercially available reagents. ${ }^{4-8}$

We recently reported the several complex based catalyst systems that have a broad substrate scope and are capable of using tetrabutylammonium peroxomonosulfate (TBAOX) as the oxidant. ${ }^{9-15}$ To have practical laboratory scale and green protocol, instead of using TBAOX oxidant which is commercially unavailable, prepared from expensive reagents, very short-term shelf-stability (3 days), we use the green oxidants such

*For correspondence as $\mathrm{tBuOOH}$ in this work. The present catalyst system shows considerably high catalytic activity, enabling efficient oxidation of primary and secondary alcohols with $\mathrm{tBuOOH}$, without overoxidation to the carboxylic acid. All the reactions were carried out in ethanol, a green solvent. This work deals with the synthesis and characterization of a new Schiff base ligand obtained by the condensation reaction of 2-hydroxynaphthalene-1carbaldehyde and 1-amino-2-propanol and its $\mathrm{Cu}$ (II) complex as catalyst (scheme 1). The coordination behavior of the Schiff base towards transition metal ions was investigated via FT-IR, UV-Vis and single crystal X-ray diffraction analysis. The geometry of the complex has been optimized using the B3LYP level of theory.

\section{Experimental}

\subsection{Materials and measurements}

$\mathrm{CuCl}_{2} \cdot 2 \mathrm{H}_{2} \mathrm{O}$ (Merck India Ltd), 2-hydroxynaphthalene1-carbaldehyde and 1-amino-2-propanol (Sigma-Aldrich, USA) were purchased. All the chemicals and solvents employed for the synthesis were of analytical grade 


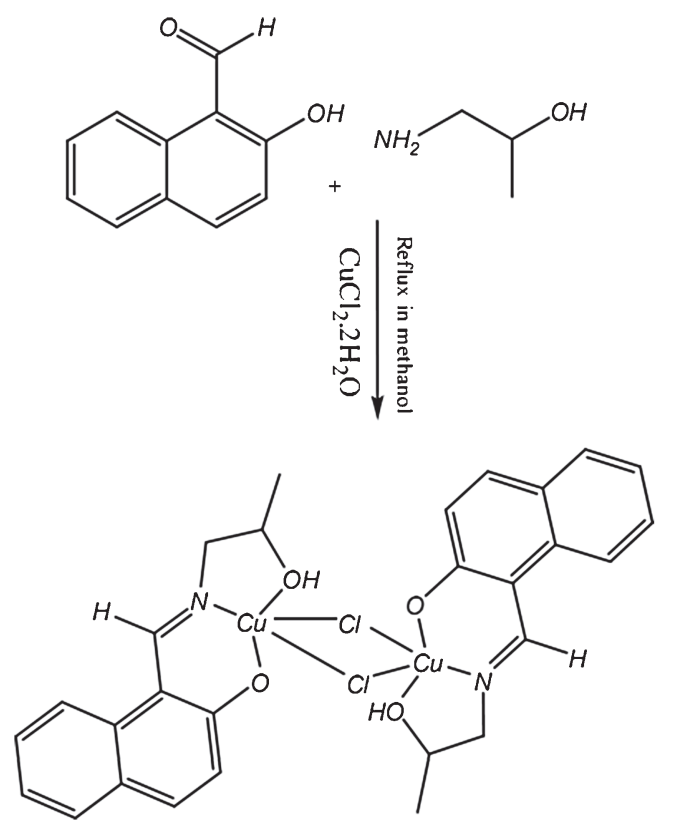

Scheme 1. Schematic representation of the synthesis of $\left[(\mathrm{HL}) \mathrm{Cu}\left(\mu_{2}-\mathrm{Cl}\right)_{2} \mathrm{Cu}(\mathrm{HL})\right] * 1.5 \mathrm{CH}_{3} \mathrm{OH}$.

and used as received without further purification. FTIR spectra of the ligand and the complex in the 4000$400 \mathrm{~cm}^{-1}$ region as $\mathrm{KBr}$ disks were recorded on a Thermo SCIENTIFIC model NICOLET iS10 spectrophotometer. The electronic spectra were recorded on a PG instruments Ltd, T70/T80 series (UV-Vis) spectrometer using HPLC grade methanol as solvent in the range $800-200 \mathrm{~nm}$. NMR spectra were recorded on a Bruker Avance DPX $500 \mathrm{MHz}$ instrument with TMS as the internal standard, using DMSO as the solvent. Mass spectra were recorded on a Shimadzu GC-MSQP5050A. Purity determinations of the products were accomplished by GC-FID on a Agilent 6890 instrument by using a $30 \mathrm{~m}, 0.32 \mathrm{~mm}$ ID, and 1 micrometer coating capillary column and also on YL instrument by using a $60 \mathrm{~m}, 0.32 \mathrm{~mm} \mathrm{ID}$, and 0.5 micrometer coating capillary column.

\subsection{Synthesis}

2.2a Synthesis of the Schiff base ligand (E)-1-(((2hydroxypropyl)imino)methyl)naphthalen-2-ol $\left(H_{2} L\right)$ : The asymmetric tridentate Schiff base $\mathrm{H}_{2} \mathrm{~L}$ was obtained by addition of a solution of $0.01 \mathrm{~mol} 1$-amino-2-propanol $(0.75 \mathrm{~g})$ in methanol $(10 \mathrm{~mL})$ to a solution of $0.01 \mathrm{~mol}$ 2-hydroxynaphthalene-1-carbaldehyde $(1.72 \mathrm{~g})$ in $10 \mathrm{~mL}$ methanol and the reaction mixture was stirred and heated to reflux for $1 \mathrm{~h}$. The yellow precipitate that formed was filtered off and dried in air. The crude product was recrystallized from $\mathrm{CHCl}_{3}$-hexane $(1 / 4 \mathrm{v} / \mathrm{v})$. Yield: $90 \%$ (1.52 g). M.p.:46-48 ${ }^{\circ} \mathrm{C}$. IR ( $\left.\mathrm{KBr} \operatorname{disc}, \mathrm{cm}^{-1}\right): 3224\left(v_{\mathrm{OH}}\right)$, $1636\left(v_{\mathrm{C}=\mathrm{N}}\right), 1545\left(v_{\mathrm{C}=\mathrm{C}}\right) ;{ }^{1} \mathrm{H}$ NMR (500 MHz, DMSO) $\delta_{\mathrm{ppm}}: 1.38(\mathrm{~d}, J=6.3,3 \mathrm{H}), 3.51\left(\mathrm{dd}, J_{1}=13, J_{2}=7.5\right.$, $1 \mathrm{H}), 3.75\left(\mathrm{dd}, J_{1}=13.2, J_{2}=3.4,1 \mathrm{H}\right), 4.17(\mathrm{~m}, 1 \mathrm{H})$, $6.86(\mathrm{~d}, J=9.2,1 \mathrm{H}), 7.21(\mathrm{t}, J=7,1 \mathrm{H}), 7.43(\mathrm{t}, J=$ $9.1,1 \mathrm{H}), 7.46(\mathrm{~d}, J=7.8,1 \mathrm{H}), 7.53(\mathrm{~d}, J=9.2,1 \mathrm{H})$, $7.82(\mathrm{~d}, J=8.35,1 \mathrm{H}), 8.74(\mathrm{~s}, 1 \mathrm{H}), 14.1(\mathrm{~s}, 1 \mathrm{H}) ;{ }^{13} \mathrm{C}$ NMR $(500 \mathrm{MHz}, \mathrm{DMSO}) \delta_{\mathrm{ppm}}: 21.15,67.17,118.34$, $123.17,124.71,126,60,128.41,129.63,138.06$; MS: $\mathrm{m} / \mathrm{z} 229\left(\mathrm{M}^{+}\right)$.

2.2b Synthesis of the $\left[(\mathrm{HL}) \mathrm{Cu}(\mu 2-\mathrm{Cl})_{2} \mathrm{Cu}(\mathrm{HL})\right] * 1.5 \mathrm{CH}_{3}$ OH complex: To $0.01 \mathrm{~mol} \mathrm{H}_{2} \mathrm{~L}$ ligand $(2.29 \mathrm{~g})$ was added 0.01 mol dihydrate copper (II) chloride $(1.704 \mathrm{~g}$ ) in $10 \mathrm{~mL}$ methanol. The reaction mixture was stirred under reflux condition for $2 \mathrm{~h}$ and a green precipitate was removed by filtration. The resulting deep green solution was then left undisturbed. The complex was recrystallized from methanol and is quite air stable as solids and also in solution. After 7 days, dark green, block-shaped, X-ray diffraction quality single crystals appeared. The product was secured in $62 \%$ yield. M.p.: $>250^{\circ} \mathrm{C}$. IR $(\mathrm{KBr}$ disc, $\left.\mathrm{cm}^{-1}\right): 1623\left(v_{\mathrm{C}=\mathrm{N}}\right), 1543\left(v_{\mathrm{C}=\mathrm{C}}\right), 560\left(v_{\mathrm{Cu}-\mathrm{O}}\right)$ and $480\left(v_{\mathrm{Cu}-\mathrm{N}}\right)$.

\subsection{Crystallographic Data Collection Structure Refinement and Computational methods}

Single-crystal X-ray diffraction data for the complex were collected on a Bruker APEX II equipped with a $\mathrm{CCD}$ area detector and utilizing $\mathrm{Mo}-\mathrm{K} \alpha$ radiation $(\lambda=0.71073 \AA)$ at room temperature. Data were collected and reduced by SMART and SAINT software in the Bruker [SHELXTL.97] and then solved. ${ }^{17}$ The structures were solved by direct methods ${ }^{16}$ packages. CCDC-968909 contains the supplementary ${ }^{18}$ by least squares refinement on $\mathrm{F}^{2}$. Crystallographic data which can be obtained free of charge from the Cambridge Crystallographic Data Centre via www.ccdc.cam.ac.uk/ data_request/cif.

The Gaussian 03W program suite ${ }^{19}$ was used for all quantum chemistry computations. The geometry optimizations were carried out at B3LYP method with LANL2DZ basis set. Harmonic vibrational frequencies were evaluated at the same level in order to compute the zero point vibrational energy (ZPVE) correction. The nature of the intramolecular interactions was studied by means of the Bader theory of atoms in molecules (AIMs). The calculated electron density, $\rho$, and its second derivative, $\nabla^{2} \rho$ were used for describing the nature of the intramolecular interactions. The AIM2000 program was used to find BCPs and to analysis them. ${ }^{20}$

\subsection{Oxidation Procedure}

To a solution of the alcohol $(0.5 \mathrm{mmol})$ and complex (scheme $1 ; 0.01 \mathrm{mmol}$ ) in ethanol $(5 \mathrm{~mL})$ was added 
tBuOOH $(0.5 \mathrm{mmol})$, and the reaction mixture was stirred in air at $80^{\circ} \mathrm{C}$ for the required time. GC monitored the reaction progress and the yields of the products. Further purification was achieved by silica chromatography.

\section{Results and Discussion}

The ligand, (E)-1-(((2-hydroxypropyl)imino)methyl)naphthalen-2-ol $\left(\mathrm{H}_{2} \mathrm{~L}\right)$, which is stable in air, was characterized by IR, UV-Vis, ${ }^{1} \mathrm{H}$ NMR, ${ }^{13} \mathrm{CNMR}$ spectra and mass spectrometry. Copper complex $\left[(\mathrm{HL}) \mathrm{Cu}\left(\mu_{2}-\mathrm{Cl}\right)_{2} \mathrm{Cu}(\mathrm{HL})\right]$ $* 1.5 \mathrm{CH}_{3} \mathrm{OH}$ was prepared by the reaction of $\mathrm{H}_{2} \mathrm{~L}$ with dihydrate copper (II) chloride. This new binuclear $\mathrm{Cu}$ (II) complex, containing two the tridentate Schiff base ligands and chlorobridged $\mathrm{Cu}(\mu-\mathrm{Cl})_{2} \mathrm{Cu}$, was characterized by UV-visible, IR spectroscopy and single-crystal X-ray analysis. The IR spectra of complex in $\mathrm{KBr}$ matrix confirm that the strong absorption band at $1623 \mathrm{~cm}^{-1}$ can be assigned to the imine stretching frequency of the coordinated ligand, whereas for the free ligand molecule the same band is observed at $1636 \mathrm{~cm}^{-1}$. The shift of this band towards lower frequency on complexation with the metal suggests coordination to the metal ion through imine nitrogen atom. ${ }^{21,22}$ A very strong band of $v_{(\mathrm{C}-\mathrm{O})}$ mode at about $1187 \mathrm{~cm}^{-1}$ and the $\mathrm{C}=\mathrm{C}$ vibration band of the aromatic ring at $1476 \mathrm{~cm}^{-1}$ are observed. Ligand coordination to the metal center is substantiated by the single bands appearing at 560 and $480 \mathrm{~cm}^{-1}$ which correspond to the vibrations of $\mathrm{Cu}-\mathrm{O}$ and $\mathrm{Cu}-\mathrm{N}$ bonds, respectively. ${ }^{23}$ On the other hand, the broad band at about $2969 \mathrm{~cm}^{-1}$ is attributable to $\mathrm{C}-\mathrm{H}$ stretching vibrations of the lattice methanol molecule. The electronic spectra of the $\mathrm{H}_{2} \mathrm{~L}$ ligand and the complex in methanol are in good agreement with their geometry. The two strong absorption bands in the UV region 227 and $238 \mathrm{~nm}$ are clearly charge transfer in origin attributed to the transition from the coordinated unsaturated ligand to the metal ion (LMCT). Again, the intense high energy bands at about 315 and $400 \mathrm{~nm}$ may be assigned to the intraligand $\pi \rightarrow \pi^{*}$ and $\mathrm{n} \rightarrow \pi^{*}$ transitions, respectively. The broad low-intensity absorption band centered at $650 \mathrm{~nm}$ is a typical $\mathrm{d}-\mathrm{d}$ band for the copper (II) ion. ${ }^{24}$

\subsection{Crystal structure description of the complex and theoretical studies}

The $\left[(\mathrm{HL}) \mathrm{Cu}\left(\mu_{2}-\mathrm{Cl}\right)_{2} \mathrm{Cu}(\mathrm{HL})\right] * 1.5 \mathrm{CH}_{3} \mathrm{OH}$ complex crystallizes as dark green single crystals in the space group $\mathrm{P}-1$ as seen from table S1 (Supporting Information). The unit cell contains two distinct entities of $[\mathrm{Cu}(\mathrm{HL}) \mathrm{Cl}]_{2}^{*}$ $1.5 \mathrm{CH}_{3} \mathrm{OH}$. An ORTEP view of the complex is shown in figure 1 . The geometry of metal complex as determined by $x$-ray crystal structure analysis was fully optimized at the above mentioned level of theory. The calculated bond lengths and bonds are in good agreement with the experimental values (table 1). The (E)-1-(((2-hydroxypropyl)imino)methyl)naphthalen-2-ol ligand is coordinated to the $\mathrm{Cu}(\mathrm{II})$ ion via its imine nitrogen, alkoxy oxygen and deprotonated phenolic oxygen atoms and the coordination sphere of $\mathrm{Cu}(\mathrm{II})$ is completed by the two bridging chloride anions. The crystal structure reveals that there are two complexes with three lattice methanol molecules (figure 2). The PXRD pattern of the complex has shown sharp intense peaks throughout the spectrum. It is indicating crystalline nature of the sample. The particle size has been calculated using Scherrer's formula $\mathrm{t}=0.9 \lambda / \mathrm{B} \cos \theta$, where $\mathrm{t}$ is the particle size (same unit as $\lambda$ ), $\mathrm{B}$ is half width (in radians) of diffraction line, $\theta$ is the Bragg angle and $\lambda$ is the wavelength. The particle

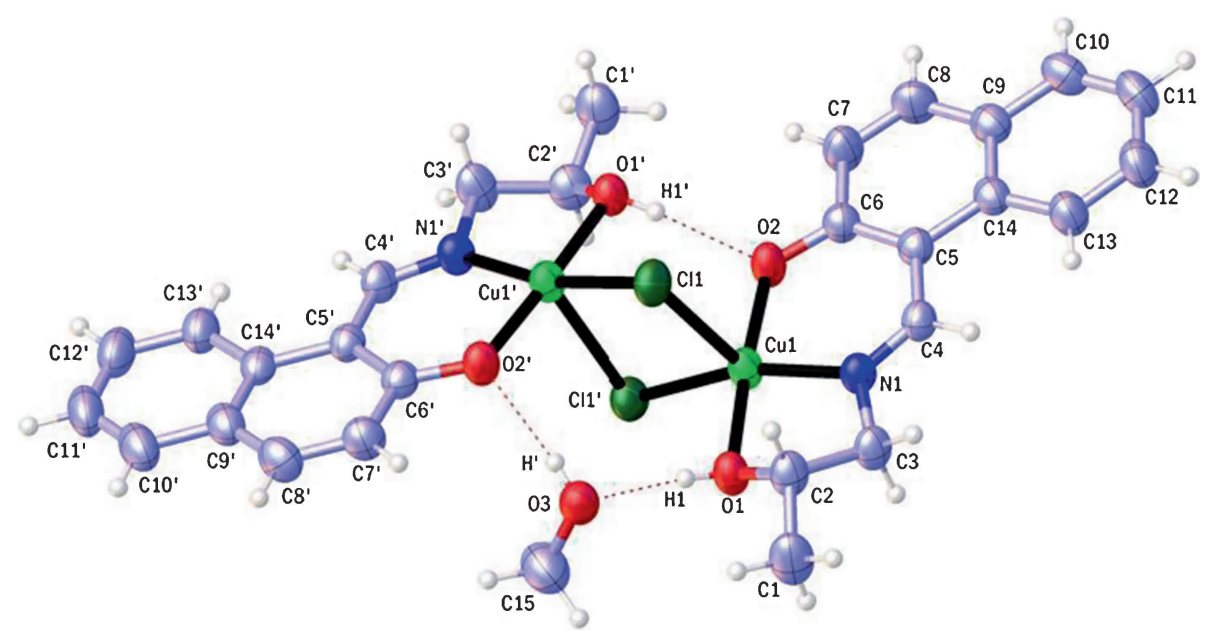

Figure 1. ORTEP view showing the molecular structure of $\left[(\mathrm{HL}) \mathrm{Cu}(\mu 2-\mathrm{Cl})_{2} \mathrm{Cu}(\mathrm{HL})\right]$ $* 1.5 \mathrm{CH}_{3} \mathrm{OH}$ with the atomic numbering scheme. The disordered $\mathrm{CH}_{3} \mathrm{OH}$ are omitted for clarity. Atomic thermal ellipsoids are presented at the $50 \%$ probability level. 
Table 1. Selected bond lengths and bond angles for $\left[(\mathrm{HL}) \mathrm{Cu}(\mu 2-\mathrm{Cl})_{2} \mathrm{Cu}(\mathrm{HL})\right] * 1.5 \mathrm{CH}_{3} \mathrm{OH}$ complex.

\begin{tabular}{|c|c|c|c|c|c|}
\hline Parameter & $\mathrm{X}$-ray analysis & DFT & Parameter & $\mathrm{X}$-ray analysis & DFT \\
\hline \multicolumn{6}{|c|}{ Selected bond distances } \\
\hline $\mathrm{Cu}(1)-\mathrm{Cl}(1)$ & 2.763 & 2.640 & $\mathrm{Cu}\left(1^{\prime}\right)-\mathrm{O}\left(2^{\prime}\right)$ & 1.902 & 1.954 \\
\hline $\mathrm{O}(1)-\mathrm{C}(2)$ & 1.443 & 1.470 & $\mathrm{Cu}\left(1^{\prime}\right)-\mathrm{N}\left(1^{\prime}\right)$ & 1.916 & 1.996 \\
\hline $\mathrm{O}(1)-\mathrm{H}(1)$ & 0.792 & 1.057 & $\mathrm{Cu}\left(1^{\prime}\right)-\mathrm{O}\left(1^{\prime}\right)$ & 2.047 & 2.044 \\
\hline $\mathrm{O}(2)-\mathrm{C}(6)$ & 1.324 & 1.339 & $\mathrm{Cu}\left(1^{\prime}\right)-\mathrm{Cl}(1)$ & 2.258 & 2.475 \\
\hline $\mathrm{O}\left(2^{\prime}\right)-\mathrm{C}\left(6^{\prime}\right)$ & 1.312 & 1.341 & $\mathrm{Cu}(1)-\mathrm{O}(2)$ & 1.913 & 1.953 \\
\hline $\mathrm{O}\left(1^{\prime}\right)-\mathrm{C}\left(2^{\prime}\right)$ & 1.453 & 1.474 & $\mathrm{Cu}(1)-\mathrm{N}(1)$ & 1.927 & 1.985 \\
\hline $\mathrm{O}\left(1^{\prime}\right)-\mathrm{H}\left(1^{\prime}\right)$ & 0.783 & 1.015 & $\mathrm{Cu}(1)-\mathrm{O}(1)$ & 1.984 & 1.994 \\
\hline $\mathrm{N}(1)-\mathrm{C}(4)$ & 1.284 & 1.307 & $\mathrm{Cu}(1)-\mathrm{Cl}\left(1^{\prime}\right)$ & 2.260 & 2.433 \\
\hline \multicolumn{6}{|c|}{ Selected bond angles $\left({ }^{\circ}\right)$} \\
\hline $\mathrm{N}(1)-\mathrm{Cu}(1)-\mathrm{Cl}\left(1^{\prime}\right)$ & 161.5 & 156.7 & $\mathrm{O}\left(2^{\prime}\right)-\mathrm{Cu}\left(1^{\prime}\right)-\mathrm{O}\left(1^{\prime}\right)$ & 174.8 & 172.0 \\
\hline $\mathrm{O}(1)-\mathrm{Cu}(1)-\mathrm{Cl}\left(1^{\prime}\right)$ & 91.4 & 89.4 & $\mathrm{~N}\left(1^{\prime}\right)-\mathrm{Cu}\left(1^{\prime}\right)-\mathrm{O}\left(1^{\prime}\right)$ & 82.6 & 82.8 \\
\hline $\mathrm{O}(2)-\mathrm{Cu}(1)-\mathrm{Cl}(1)$ & 91.0 & 92.9 & $\mathrm{O}\left(2^{\prime}\right)-\mathrm{Cu}\left(1^{\prime}\right)-\mathrm{Cl}(1)$ & 94.4 & 95.4 \\
\hline $\mathrm{N}(1)-\mathrm{Cu}(1)-\mathrm{Cl}(1)$ & 103.9 & 103.9 & $\mathrm{~N}\left(1^{\prime}\right)-\mathrm{Cu}\left(1^{\prime}\right)-\mathrm{Cl}(1)$ & 167.2 & 152.4 \\
\hline $\mathrm{O}(1)-\mathrm{Cu}(1)-\mathrm{Cl}(1)$ & 88.4 & 91.4 & $\mathrm{O}\left(1^{\prime}\right)-\mathrm{Cu}\left(1^{\prime}\right)-\mathrm{Cl}(1)$ & 90.7 & 87.5 \\
\hline $\mathrm{Cl}\left(1^{\prime}\right)-\mathrm{Cu}(1)-\mathrm{Cl}(1)$ & 93.2 & 98.6 & $\mathrm{O}(2)-\mathrm{Cu}(1)-\mathrm{N}(1)$ & 92.5 & 91.6 \\
\hline $\mathrm{Cu}\left(1^{\prime}\right)-\mathrm{Cl}(1)-\mathrm{Cu}(1)$ & 86.4 & 82.3 & $\mathrm{O}(2)-\mathrm{Cu}(1)-\mathrm{O}(1)$ & 174.4 & 174.5 \\
\hline $\mathrm{C}(2)-\mathrm{O}(1)-\mathrm{Cu}(1)$ & 110.2 & 107.7 & $\mathrm{~N}(1)-\mathrm{Cu}(1)-\mathrm{O}(1)$ & 82.2 & 83.2 \\
\hline
\end{tabular}

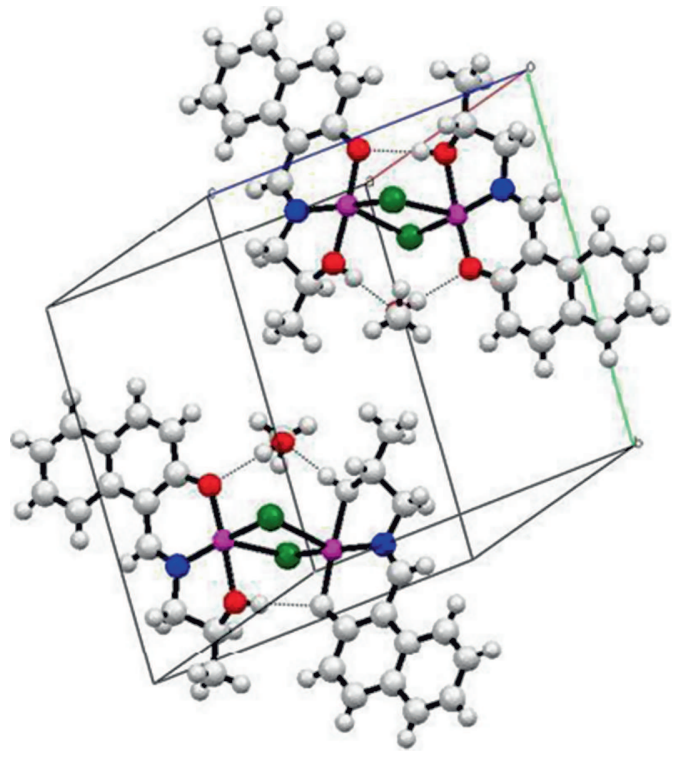

Figure 2. Mercury view shows the unit cell of $[\mathrm{Cu}(\mathrm{HL}) \mathrm{Cl}]_{2}$ with ball and stick representation.

size of $\mathrm{Cu}$ (II) complex was found to be around $27 \mathrm{~nm}$. The XRD pattern of the complex is shown in figure S2 (Supporting Information).

There are two common structures for a five coordinated $\mathrm{Cu}^{\mathrm{II}}$ center, square-pyramidal (SP) or trigonalbipyramidal (TBP) geometry, which can be evaluated by the addison distortion index $(\tau) . \tau$ defined as $\tau=[\mid \theta-$ $\Phi \mid / 60]$, where $\theta$ and $\Phi$ are the two largest coordination angles and $\tau=0$ for perfect SP and 1 for ideal TBP. ${ }^{25,26}$ The calculated $\tau$ of $\mathrm{Cu}(1)$ and $\mathrm{Cu}(2)(0.21583(3)$ and
0.12733(3), respectively) also confirmed the distorted SP geometry for each copper ion. It should be noted that the active Jahn-Teller distortion of the copper (II) ion causes that equatorial $\mathrm{Cu}-\mathrm{Cl}$ bonds are shorter than axial bonds for each copper. For example, 2.7627(7) $\AA$ and 2.2606(6) $\AA$ are related to the axial and equatorial $\mathrm{Cu}-\mathrm{Cl}$ bonds for $\mathrm{Cu}(1)$, respectively.

DFT calculations at the B3LYP/LANL2DZ level of theory using the GAUSSIAN 03 were carried out. The Bader's quantum theory ${ }^{27,28}$ of atoms in molecules (QTAIM) was also applied to get more details about the nature of the intramolecular interactions in this complex. According to this theory, when two neighboring atoms are chemically bonded, a critical point for bond formation appears between them. The sign of Laplacian for electron density at a bond critical point, $\nabla^{2} \rho$, reveals whether the charge is concentrated, as in a covalent bond $\left(\nabla^{2} \rho<0\right)$, or depleted, as in closed shell (electrostatic) interactions $\left(\nabla^{2} \rho>0\right)$. The calculated electron density, $\rho$, and its second derivative, $\nabla^{2} \rho$ were used for describing the nature of the intramolecular interactions. ${ }^{29-34}$ The molecular graph of the complex was obtained from the B3LYP/LANL2DZ wave function (figure S1, Supporting Information). The corresponding values of $\rho \mathrm{BCP}$ and $\nabla^{2} \rho \mathrm{BCP}$ were presented in table S2 (Supporting Information). As shown in the molecular graph of the complex, all the critical bonds between atoms have shown bonds and critical points. The comparison between the electron density of $\mathrm{Cu}-\mathrm{N}, \mathrm{Cu}-\mathrm{O}$ and $\mathrm{Cu}-\mathrm{Cl}$ bonding have shown that $\rho \mathrm{BCP}$ for the $\mathrm{Cu}-\mathrm{N}$ bonding is higher than the corresponding value for 
$\mathrm{Cu}-\mathrm{O}$ and $\mathrm{Cu}-\mathrm{Cl}$. As a consequence, the strength of the $\mathrm{Cu}-\mathrm{N}$ bond is greater than the other. Furthermore, the calculated electron densities indicate that $\mathrm{Cu}-\mathrm{N}, \mathrm{Cu}-\mathrm{O}$ and $\mathrm{Cu}-\mathrm{Cl}$ bondings have low $\rho \mathrm{BCP}$ (about 0.0851, 0.0797 and 0.0379 , respectively) and positive $\nabla^{2} \rho \mathrm{BCP}$ values. These properties are typical for close shell interaction for them.

The analysis of the wave function indicates that the electron adsorption corresponds to the transition from the ground state to the first excited state and is mainly described by one- electron excitation from the highest occupied molecular orbital (HOMO) to the lowest unoccupied molecular orbital (LUMO). The HOMO and LUMO orbitals for the investigated complex are shown in figure 3. The HOMO of the complex has shown antibonding character at $\mathrm{Cu}-\mathrm{Cl}$. There is no electronic projection over the methanol group. The LUMO has a larger electronic projection over $\mathrm{Cu}$ atom in this complex.

\subsection{Oxidation of alcohols}

Oxidation of benzyl alcohol was studied exclusively for solvent effect, catalyst concentration, oxidant volume, reaction time and the results of the study are as follows. The oxidation of benzyl alcohol in the presence of tBuOOH without catalyst was slow (7\% after $24 \mathrm{~h}$ ). By addition $2 \mathrm{~mol} \%$ catalyst, the conversion in reaction was enhanced markedly (50\% after $24 \mathrm{~h}$ ) and increasing the mole percentage of catalyst up to $10 \%$ did not affect the rate of reaction. The influence of axial nitrogenous bases having dramatic effects on the rate and selectivity in the oxidation reactions catalyzed by various transition metal complexes such as porphyrin ${ }^{35}$ and salen ${ }^{36}$ catalysts has also been studied Imidazole and pyridine as commonly used axial base were added and no improvement in the reaction rate was observed. Water and ethanol were investigated as green media for the reaction (net reaction, 2\%,50\% respectively after $24 \mathrm{~h}$ ) and ethanol was found to be the best solvent in terms of conversion rate and benzaldehyde yield. The reaction rates and products yields were found to be poor at room temperature and all the reactions were conducted at reflux temperature $\left(80^{\circ} \mathrm{C}\right)$. The best yield of benzaldehyde was obtained during oxidation of benzyl alcohol (1 mmol) using $2 \mathrm{~mol} \%$ of catalyst with $1 \mathrm{mmol}$ of tBuOOH in $1 \mathrm{~mL}$ ethanol for $1 \mathrm{~h}$ at $80^{\circ} \mathrm{C}$.

Primary benzylic alcohols bearing a variety of electron donating and electron withdrawing groups undergo efficient and selective oxidation to the aldehyde, without overoxidation to the carboxylic acid. It represents a practical alternative to traditional reagents and methods for the oxidation of primary and secondary alcohols Benzylic alcohols are generally excellent substrates for this catalyst (table 2, entries 1-7). Electronic and steric effects do not seem to have a significant effect on the isolated yields for electronrich and electron-poor benzylic alcohols. When we applied this catalytic system for the oxidation of secondary alcohols, good/high yields of ketones were secured (table 2, entries 8-11). The good conversion of less reactive primary and secondary aliphatic alcohols to their corresponding carbonyl compound without overoxidation to carboxylic products is a notable feature of this oxidation method.

To prove the high efficiency and relative stability of this noble catalyst, the turnover number (TON) and turnover frequency (TOF) in the oxidation of benzylic alcohol were investigated. In this oxidation protocol, 5000:10000:1 molar ratio was used for substrate/oxidant/catalyst and impressive turnover frequency $(\mathrm{TOF}=1640 / \mathrm{h})$ and turnover number $(\mathrm{TON}=5000 \mathrm{in} 24 \mathrm{~h}$ ) were obtained.

After completion of the oxidation of benzylic alcohol, $2 \mathrm{~mol} \%$ of catalyst with $1 \mathrm{mmol}$ of $\mathrm{tBuOOH}$ was added again to reaction media and was stirred for another $1 \mathrm{~h}$. After repeating three times, the solvent was dried under vacuum washed with diethyl ether and used directly for the next round of reaction without further purification. Comparison of the IR spectra of the used [(HL)Cu( $\mu 2-$ $\left.\mathrm{Cl})_{2} \mathrm{Cu}(\mathrm{HL})\right] * 1.5 \mathrm{CH}_{3} \mathrm{OH}$ (figure 4) with fresh catalyst showed that the structure and morphology of the catalyst remained almost intact after four recoveries.

Thus, the methodology described herein is cost effective and environmentally benign due to the use of

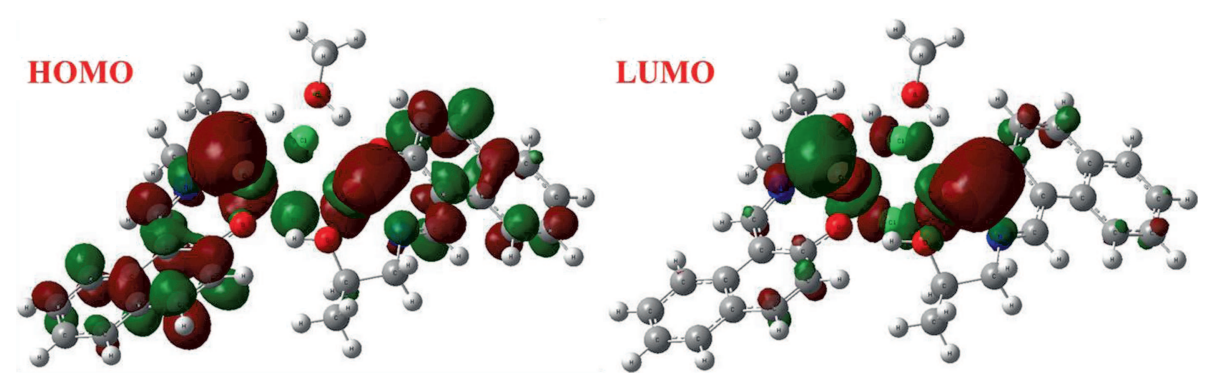

Figure 3. HOMO and LUMO orbitals of complex $\left[(\mathrm{HL}) \mathrm{Cu}(\mu 2-\mathrm{Cl})_{2} \mathrm{Cu}(\mathrm{HL})\right]$ $* 1.5 \mathrm{CH}_{3} \mathrm{OH}$ obtained with B3LYP/LANL2DZ level of theory. 
ethanol and $\mathrm{tBuOOH}$ as a reaction medium and oxidant. the use of a semi scale-up procedure (10 mmol) for Further, catalyst is stable and the reaction does not need nitrogen donors. These advantages of this high yielding oxidation method offered ready scalability. For example the oxidation of benzylic alcohol in the presence of $\left[(\mathrm{HL}) \mathrm{Cu}\left(\mu_{2}-\mathrm{Cl}\right)_{2} \mathrm{Cu}(\mathrm{HL})\right] * 1.5 \mathrm{CH}_{3} \mathrm{OH}$ led to the isolation of the related aldehyde in $91 \%$ yield.

Table 2. Oxidation of alcohols with $\mathrm{tBuOOH}$ catalyzed by $\left[(\mathrm{HL}) \mathrm{Cu}(\mu 2-\mathrm{Cl})_{2} \mathrm{Cu}(\mathrm{HL})\right] * 1.5 \mathrm{CH}_{3} \mathrm{OH}$ complex $^{\mathrm{a}}$.

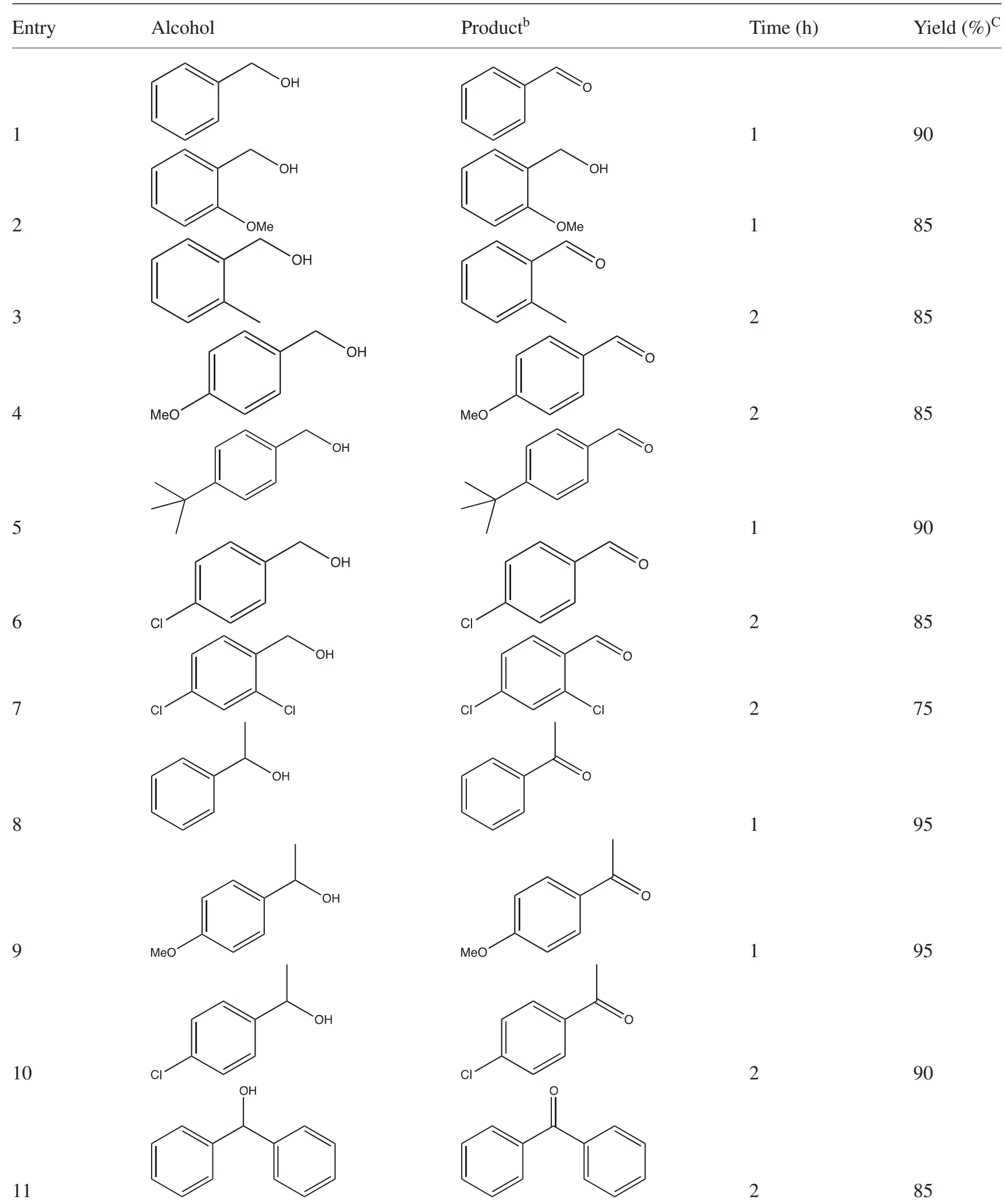


Table 2. (continued)

Entry Alcohol Time (h)

${ }^{\mathrm{a}}$ The reactions were run under air at $80^{\circ} \mathrm{C}$ and the molar ratio of alcohol:

TBAOX:catalyst was 100:100:2.

${ }^{\mathrm{b}}$ All the products were identified by comparison with commercial and authentic samples.

${ }^{\mathrm{c}}$ Yields of isolated products. No over oxidation products were observed for all substrates.

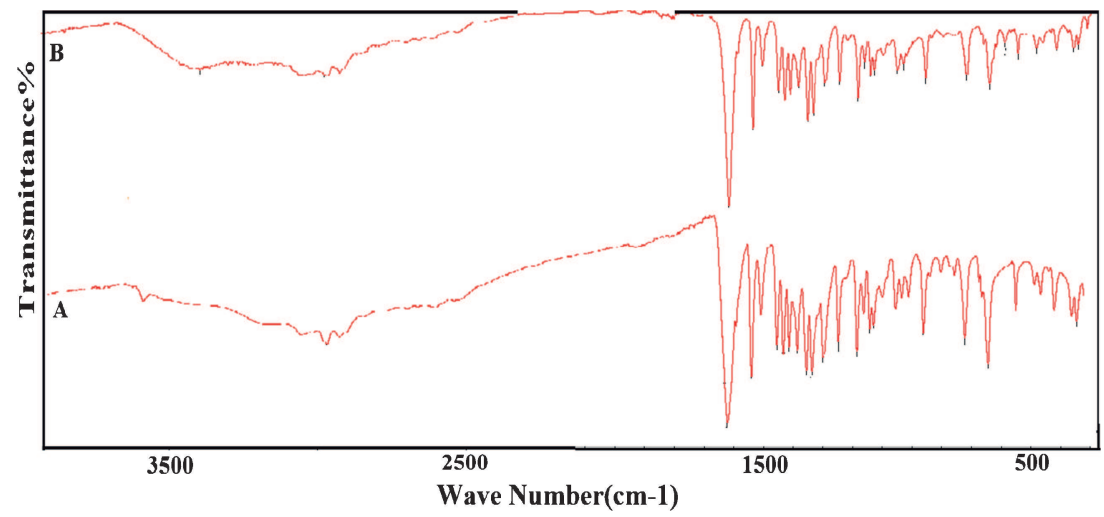

Figure 4. FT-IR spectra of fresh $\left[(\mathrm{HL}) \mathrm{Cu}\left(\mu_{2}-\mathrm{Cl}\right)_{2} \mathrm{Cu}(\mathrm{HL})\right]^{*} 1.5 \mathrm{CH}_{3} \mathrm{OH}(\mathrm{A})$ and after 4 reuses (B).

\section{Conclusions}

A novel $\mathrm{Cu}$ (II) complex, [(HL) $\left.\mathrm{Cu}\left(\mu_{2}-\mathrm{Cl}\right)_{2} \mathrm{Cu}(\mathrm{HL})\right]$ $* 1.5 \mathrm{CH}_{3} \mathrm{OH}$ was synthesized, using (E)-1-(((2-hydroxypropyl)imino)methyl)naphthalen-2-ol $\left(\mathrm{H}_{2} \mathrm{~L}\right)$ as tridentate OON donor Schiff base ligand and characterized by IR, UV-Visible spectroscopy and single-crystal X-ray analysis. This complex was used as a new catalyst for a practical laboratory-scale oxidation strategy using tBuOOH and ethanol as oxidant and green solvent, respectively. The high turnover number and turnover frequency have confirmed the stability and efficiency of the catalyst.

\section{Supporting Information}

Figures $\mathrm{S} 1$ and $\mathrm{S} 2$ and tables $\mathrm{S} 1$ and $\mathrm{S} 2$ are available at www.ias.ac.in/chemsci.

\section{Acknowledgements}

We are thankful to University of Jiroft and Vali-e-Asr University of Rafsanjan Research Council for their support on this work. We also thank Dr. Emilio Perez for his valuable comments to improve our project.

\section{References}

1. Busacca C A, Fandrick D R, Song J J and Senanayake C H 2011 Adv. Synth. Catal. 3531825

2. Arends W C E and Sheldon R A 2010 In Modern Oxidation Methods 2nd ed. J E Bäckvall (ed.) (Weinheim: Wiley-VCH) pp. 147-185

3. Hoover J M, Steves J E and Stahl S S 2012 Nature Protocols 71161

4. Fatiadi A J 1976 Synthesis 65

5. Taylor R J K, Reid M, Foot J and Raw S A 2005 Acc. Chem. Res. 38851

6. Pfitzner K E and Moffatt J G 1963 J. Am. Chem. Soc. 85 3027

7. Mancuso A J, Brownfain D S and Swern D 1979 J. Org. Chem. 444148

8. Tidwell T T 1990 Synthesis 857

9. Moreno A L, Tejeda D C, Calbo J, Naeimi A, Bermejo F A, Ortí E and Pérez E M 2014 Chem. Commun. 50 9372

10. Aguiló J, Naeimi A, Bofill R, Bunz H M, Llobet A, Escriche L, Sala X and Albrech M 2014 New J. Chem. 381980

11. Rezaeifard A, Jafarpour M, Naeimi A and Haddad R 2012 Green Chem. 143386

12. Rezaeifard A, Jafarpour M, Naeimi A and Salimi M 2012 Inorg. Chem. Commun. 15230

13. Rezaeifard A, Jafarpour M and Naeimi A 2011 Catal. Commun. 16240 
14. Rezaeifard A, Jafarpour M, Naeimi A and Mohammadi K 2012 J. Mol. Catal. A: Chem. 357141

15. Rezaeifard A, Jafarpour M, Naeimi A and Kaafi S 2011 Catal. Commun. 12761

16. Bruker, 1999 SMART and SAINT. Bruker AXS Inc., Madison, Wisconsin, USA

17. Burla M C, Caliandro R, Camalli M, Carrozzini B, Cascarano G L, De Caro L, Giacovazzo C, Polidori G and Spagna R 2005 J. Appl. Crystallogr. 38381

18. Sheldrick G M 1997 SHELXL97. Program for crystal structure refinement. University of Gottingen, Germany

19. Frisch M J, Trucks G W, Schlegel H B, Scuseria G E, Robb M A, Cheeseman J R, Montgomery J A Jr, Vreven T., Kudin K N, Burant J C, Millam J M, Iyengar S S, Tomasi J, Barone $\mathrm{V}$, Mennucci $\mathrm{B}$, Cossi M, Scalmani G, Rega N, Petersson G A, Nakatsuji H, Hada M, Ehara M, Toyota K, Fukuda R, Hasegawa J, Ishida M, Nakajima T, Honda Y, Kitao O, Nakai H, Klene M, Li X, Knox J E, Hratchian H P, Cross J B, Bakken V, Adamo C, Jaramillo J, Gomperts R, Stratmann R E, Yazyev O, Austin A J, Cammi R, Pomelli C, Ochterski J W, Ayala P Y, Morokuma K, Voth G A, Salvador P, Dannenberg J J, Zakrzewski V G, Dapprich S, Daniels A D, Strain M C, Farkas O, Malick D K, Rabuck A D, Raghavachari K, Foresman J B, Ortiz J V, Cui Q, Baboul A G, Clifford S, Cioslowski J, Stefanov B B, Liu G, Liashenko A, Piskorz P, Komaromi I, Martin R L, Fox D J, Keith T, Al-Laham M A, Peng C Y, Nanayakkara A, Challacombe M, Gill P M W, Johnson B, Chen W, Wong M W, Gonzalez C and Pople J A 2004 Gaussian 03, Revision E.01 (Gaussian, Inc.: Wallingford, CT)
20. Biegler-Konig F., AIM 2000 version 1.0, 1998 University of Applied. Science, Bielefeld, Germany

21. Tarafder M, Kasbollah A, Crouse K, Ali A, Yamin B and Fun H K 2001 Polyhedron 202363

22. Vafazadeh R, Khaledi B, Willis A C and Namazian M 2011 Polyhedron 301815

23. Trzesowska-Kruszynska A 2012 J. Mol. Struc. 101772

24. Thakurta S, Roy P, Rosair G, Gómez-García C J, Garribba E and Mitra S 2009 Polyhedron 28695

25. Hathaway B, Wilkinson G, Gillard R and McCleverty J 1987 In Comprehensive Coordination Chemistry Vol. 5 (Oxford: Pergamon)

26. Addison A W, Rao T N, Reedijk J, van Rijn J and Verschoor G C 1984 J. Chem. Soc., Dalton Trans. 1349

27. Bader R F 1991 Chem. Rev. 91893

28. Bader R F 1990 In Atoms in Molecules: A Quantum Theory (London: Oxford University Press)

29. Raissi H, Yoosefian M, Mollania F and Khoshkhou S 2013 Struct. Chem. 24123

30. Raissi H, Yoosefian M and Mollania F 2012 Int. J. Quantum Chem. 1122782

31. Fazli M, Jalbout A, Raissi H, Ghiassi H and Yoosefian M 2009 J. Theor. Comput. Chem. 8713

32. Yoosefian M, Barzgari Z and Yoosefian J 2014 Struct. Chem. 259

33. Raissi H, Khanmohammadi A, Yoosefian $M$ and Mollania F 2013 Struct. Chem. 241121

34. Raissi H, Yoosefian M, Mollania F, Farzad F and Nowroozi A R 2011 Comput. Theor. Chem. 966299

35. Meunier B 1992 Chem. Rev. 921411

36. McGarrigle E M and Gilheany D G 2005 Chem. Rev. 1051563 